Al-Azhar Bull. Sci. Vol. 18, No. 1 (June.): pp. 9-19, 2007.

\title{
INHIBITION EFFECT OF SOME POLYETHYLENE GLYCOLS (PEG) ON THE CORROSION OF ALUMINUM IN 1.0 M PHOSPHORIC ACID
}

\author{
S. A. SOLIMAN
}

Chemistry Department, Faculty of Science, Al-Azhar University, Cairo, Egypt

\begin{abstract}
The effect of some polyethylene glycols (PEG) as inhibitors on the corrosion of aluminum in $1.0 \mathrm{M} \mathrm{H}_{3} \mathrm{PO}_{4}$ has been studied using weight loss and polarization measurements in various concentrations of PEG and at different temperatures. The dissolution of aluminum in phosphoric acids increases by increasing temperatures and decreases by increasing the additive concentrations. The inhibition efficienciy values proceed according to the following order of the molecular weights of the used inhibitors PEG 4000 > PEG $2000>$ PEG $1500>$ PEG 400. For relatively higher molecular weights inhibitor (beginning from 1500) the type of adsorption taking place at the surface of aluminum was physical adsorption whereas for the molecular weight. $=400$ had different behavior till $50^{\circ} \mathrm{C}$ and then the inhibition efficiency decreasing at $60^{\circ} \mathrm{C}$ indicating physical adsorptions. The lone pair of electrons of oxygen atom of hydroxyl groups play an important role in the adsorptions of additives on aluminum surface, which affected by polarization. The thermodynamic calculated values of activation and adsorption were calculated and discussed.
\end{abstract}

\section{Introduction}

Corrosion of aluminum and aluminum alloys has been the subject of numerous studies due to the importance of such materials in contemporary civilization and to their greatly industrial applications ${ }^{(1-3)}$. Many researches were devoted to study the corrosion of aluminum in different aqueous solutions ${ }^{(4-5)}$. It is very important to add corrosion inhibitors to decrease the corrosion rate of the dissolution of aluminum in such solutions ${ }^{(6)}$. The processes of adsorption of inhibitors are influenced by: the nature and surface charge of the metal, the chemical structure of organic inhibitors, the distribution of charges in the molecule and the type of electrolyte ${ }^{(7)}$. The chemisorptions are the principle type of interaction between organic inhibitors and the metal surface ${ }^{(8)}$. The adsorption of organic inhibitors mainly depends on some physicochemical properties of the molecule, related to its functional groups, to the possible steric effects and electronic density of donor atoms ${ }^{(9)}$. Recent studies have been concerned with the effect of oxygen-containing compounds such as polyethylene glycol with different molecular weights on the inhibition of aluminum corrosion $^{(10)}$. The general formula of polyethylene glycol is given by " $\mathrm{H}\left(-\mathrm{OCH}_{2}-\right.$ $\left.\mathrm{CH}_{2-}\right)_{\mathrm{n}} \mathrm{OH}$ ", for PEG 400, average value of $\mathrm{n}$ between 8.2 and 9.1, viscous, slightly 
hygroscopic and liquid, for PEG 1500,average value of $\mathrm{n}$ between 29 and 36, white, free flowing powder, for PEG 2000, average value of $n$ between 42 and 48, white solid and for PEG 4000, average value of $n$ between 68 and 84 and white flakes.

\section{Experimental}

The samples were made from commercial aluminum sheets having the following chemical composition: $\mathrm{Al} 99 \%, \mathrm{Fe} 0.2 \%, \mathrm{Cu} 0.2 \%$, Si $0.2 \%$, Ti $0.03 \%$ and $\mathrm{Zn} 0.08 \%$ (Riedel-De Haan-Germany). Phosphoric acid assay 88\% Prolabo, Arabic laboratory equipment company. For weight loss measurements, aluminum specimens were polished and cleaned according to the methods described earlier ${ }^{(11-12)}$, the corrosion of aluminum in $1.0 \mathrm{M} \mathrm{H}_{3} \mathrm{PO}_{4}$ was carried out by using sheets $(1 \times 1.5 \times 0.01 \mathrm{~cm})$, and suspended in $50 \mathrm{ml}$ of the test solutions for a known time at a desired temperatures. All solutions were prepared from ordinary distilled water, thermostated to within $\pm 0.1^{\circ} \mathrm{C}$ of the indicated temperatures. The used of polyethylene glycol (PEG) samples were prepared and delivered from EPRI ${ }^{(13)}$. The electrochemical measurements were carried out using EG \& G (Prinston Applied Research) potentiostat / galvanostat Model 372 with scan rate of $1 \mathrm{mV} / \mathrm{sec}$. from 1750 to $1000 \mathrm{mV}$. An electrolytic cell of Pyrex glass vessel capacity $250 \mathrm{ml}$ consisted of aluminum electrode in the form of sheet as a working electrode. Pt. electrode as an auxiliary electrode and saturated calomel electrode (SCE) as a reference electrode were used. The organic compounds used as inhibitors were polyethylene glycols of different molecular weights (PEG 400 - PEG 1500 - PEG 2000 and PEG 4000).

\section{Results And Discussions}

1. Weight-loss measurements.

Corrosion behavior of aluminum in $1.0 \quad \mathrm{M} \mathrm{H}_{3} \mathrm{PO}_{4}$ has been studied intemperatures ranged from $\left(20^{\circ} \mathrm{C}-60^{\circ} \mathrm{C}\right)$. Results given in Fig. (1), concern the corrosion rate determined in the absence of inhibitor. The inhibition efficiency, \%EI is defined as follows ${ }^{(14)}$;

$$
\% \mathrm{EI}=\left[\left(\mathrm{W}_{\text {non inh, }}-\mathrm{W}_{\text {inh }}\right) / \mathrm{W}_{\text {non inh. }} .\right] \times 100 ;
$$

where ; $\mathrm{W}$ non inh and $\mathrm{W}$ inh, are weight loss for the metal in the absence and presence of inhibitors respectively.

Fig. (2) shows the effect of addition of different concentrations of polyethylene glycols (PEG 400, PEG 1500, PEG 2000 and PEG 4000), on the dissolution of 
aluminum in $1.0 \mathrm{M}$ phosphoric acid solution at $30^{\circ} \mathrm{C}$. The curves indicate that an increase in inhibitor concentration decreases the dissolution of aluminum. Its also noticed - from Fig. (3), which reveals the effect of temperatures on the dissolution of aluminum - that the temperature retards the inhibition effect. In general, the inhibition efficiency of these compounds increase with increasing molecular weight. This may be due to the increase in the number of ethylene oxide groups attached in molecule ${ }^{(15)}$.

The effect of temperatures on the inhibition efficiencies are shown in Fig. (4), which shows that PEG 400 has an abnormal behavior, where the temperature accelerates the inhibition effect till $50^{\circ} \mathrm{C}$, then the adsorbed layer destroyed as a result of increasing the desorption process at $60^{\circ} \mathrm{C}$, the data are listed in Table (1). To calculate the activation thermodynamic parameters of the corrosion reaction such as the activation energy $E_{a}$, the entropy of activation $\Delta S_{a}$, free energy of activation $\Delta \mathrm{G}_{\mathrm{a}}$ and the enthalpy of activation $\Delta \mathrm{H}_{\mathrm{a}}$, Arrhenius equation ${ }^{(16)}$ was used;

$$
\mathrm{K}=\mathrm{W} / \mathrm{t}
$$

Where $\mathrm{K}$ is the specific rate constant and $\mathrm{t}$ is the immersion time

$$
\log \mathrm{K}=\log \mathrm{A}-\left(\mathrm{E}_{\mathrm{a}} / 2.303 \mathrm{RT}\right)
$$

Where, $\mathrm{A}$ is Arrhenius constant and $\mathrm{R}$ is the universal gas constant.

The values of activation thermodynamic functions were calculated from ${ }^{(17)}$,

$$
\begin{aligned}
& \mathrm{K}=(k \mathrm{~T} / h) \operatorname{Exp}\left[-\Delta \mathrm{G}_{\mathrm{a}} / \mathrm{RT}\right] \\
& \Delta \mathrm{H}_{\mathrm{a}}=\mathrm{E}_{\mathrm{a}}-\mathrm{RT} \\
& \Delta \mathrm{S}_{\mathrm{a}}=\left[\Delta \mathrm{H}_{\mathrm{a}}-\Delta \mathrm{G}_{\mathrm{a}}\right] / \mathrm{T}
\end{aligned}
$$

where $k$ is Boltzmann constant and $h$ is Blank' s constant.

From Langmuir adsorption isotherm ${ }^{(18)}$;.

$$
\begin{aligned}
& \log (\theta / 1-\theta)=\log C \beta-\left(\Delta \mathrm{G}_{\text {ads }}^{\mathrm{o}} / 2.303 \mathrm{RT}\right), \\
& \theta=\left(\mathrm{W}_{\text {non inh, }}-\mathrm{W}_{\text {inh }}\right) / \mathrm{W}_{\text {non inh }}
\end{aligned}
$$

where; $\beta$ is the adsorption equilibrium constant, $\mathrm{C}$ is the inhibitor concentration, and $\theta$ is the surface coverage of the metal surface by adsorbate

The values of enthalpy of adsorption can be calculated from the relation ${ }^{(16)}$;

$$
\log \mathrm{k}=\log \mathrm{k}_{\mathrm{o}}-\left(\Delta \mathrm{H}_{\mathrm{ads}} / 2.303 \mathrm{RT}\right)
$$

where; $\mathrm{k}$ is adsorption coefficient. and $\mathrm{k}_{\mathrm{o}}$ is a constant.

The thermodynamic parameter data were summarized in Table (2) which shows that $\Delta \mathrm{H}_{\mathrm{a}}, \Delta \mathrm{S}_{\mathrm{a}}$ of the dissolution reactions of aluminum in $1.0 \mathrm{M} \mathrm{H}_{3} \mathrm{PO}_{4}$ in presence of PEG 1500, PEG 2000, and PEG 4000 are higher as compared with those of the non-inhibited solutions, and the negative values of $\Delta \mathrm{H}_{\mathrm{ads}}$ mean that the adsorption reaction is an exothermic process ${ }^{(19)}$ and the dissolution of aluminum is difficult in 
presence of PEG additives. The values of $\Delta \mathrm{G}_{\text {ads }}$ presented in Table (2), indicate that the inhibitors are physically adsorbed on the electrode surface ${ }^{(20)}$. Data of Table (2) obviously show that, for PEGs with high molecular weights (1500, 2000 and 4000 $\mathrm{gm} \mathrm{mol}^{-1}$ ), the inhibition efficiency decreases with increasing temperature, confirming physical adsorption. On the other hand, the inhibition efficiency of low molecular weight PEG (400 gm mol${ }^{-1}$ ), obviously enhanced with rise in temperature. These results may indicate that PEG is chemisorbed on the electrode surface. It is also, polymerization takes place on the electrode surface with rise in temperature and consequently, the inhibition efficiency increases. In addition, the values of $\Delta \mathrm{S}_{\text {ads }}$ decrease with increase in temperature, this meaning that a stable ordered layer of the inhibitor is formed on the aluminum electrode surface ${ }^{(21)}$.

\section{Polarization Measurements:}

Anodic and cathodic Tafel polarization curves of the dissolution of aluminum in 1.0 $\mathrm{M}$ phosphoric acid solution was measured in the absence and presence of $0.01 \mathrm{M}$ of (PEG) additives at temperatures ranged from $30^{\circ} \mathrm{C}$ to $60^{\circ} \mathrm{C}$ as shown in Fig. (5). The data clarified that the addition of PEG inhibitor compounds shifts the corrosion potential $\mathrm{E}_{\text {corr }}$ to more negative values, thus the cathodic sits are blocked to greater extent than the anodic sites by the inhibitor molecules except PEG 400 which shifts the corrosion potential to more positive value by increasing the temperatures. It means that this compound affects anodic reaction more than cathodic one. The electrochemical parameters ( $i_{\text {corr. }}, E_{\text {corr. }}, b_{a} b_{c}$ and $\% E I$ ) associated with polarization measurements at different temperatures are listed in Table 3 , where $\mathrm{i}_{\text {corr. }}, \mathrm{E}_{\text {corr. }}, \mathrm{b}_{\mathrm{a}}, \mathrm{b}_{\mathrm{c}}$ and $\% \mathrm{EI}$ are the corrosion current density, corrosion potential, anodic and cathodic Tafel slopes and inhibition efficiency, respectively. Since the corrosion rate is directly related to the corrosion current density, the inhibition efficiency (\% EI) at different temperatures were calculated from the equations:

$$
\begin{aligned}
& \theta=1-\left(i_{\text {inh. }} / i_{\text {non inh. }}\right) \\
& \% \mathrm{EI}=\theta \times 100
\end{aligned}
$$

Where, $\mathrm{i}_{\text {inh }}$ and $\mathrm{i}_{\text {non inh }}$ are the corrosion current density in presence of inhibitor and in absence of inhibitor, respectively.

And the corrosion rate (mpy) is calculated from the equation ${ }^{(22)}$,

$$
\text { Rate }(\mathrm{mpy})=0.1285 \times \mathrm{i} \text { corr } \mathrm{x} \text { Eq.wt / d, }
$$

where, $d$; is the density and $i_{\text {corr }}$, is the corrosion current density.

The activation and adsorption thermodynamic parameters are calculated by using equations 3, 4 and 5. From polarization measurements, the data are given in Table 4. 
It is clear that $\left(\Delta \mathrm{H}_{\mathrm{ads}}\right)$ values have a negative signs which mean that an exothermic reaction takes place, except in case of PEG 400 which has a positive values, that indicated an endothermic reaction took place, these behaviors were identical to that obtained from weight loss measurements.

\section{Conclusion}

All examined PEG additive compounds act as good inhibitors for aluminum corrosion in $1.0 \mathrm{M}$ phosphoric acid solutions at all temperatures studied. The data indicated that the inhibition efficiencies decrease as the temperatures increasing. However, for PEG 400, the inhibition efficiency increases with increasing temperature. At ambient temperature the adsorption of such compounds is physical adsorption except for PEG 400 which undergoes chemical adsorption owing to the lowest number of functional groups of small molecular weight then at higher temperatures the adsorption would be physical. The lone pair of electrons of oxygen atoms of hydroxyl groups plays an important role in the adsorption processes of the additives on aluminum surface. The adsorption obeys the Langmuir adsorption isotherm. The data obtained from weight loss measurements agree well with those obtained from polarization measurements. The inhibition efficiencies of these inhibitors decrease in the following order: PEG 4000 > PEG 2000 > PEG 1500 > PEG 400.

Table (1) Values of corrosion rate and inhibition efficiency of 0.01M PEG additives at different temperatures.

\begin{tabular}{|c|c|c|c|c|c|}
\hline Comp. & $\mathrm{T}(\mathrm{K})$ & $\begin{array}{c}\mathrm{W}_{\text {noninh. }} \\
\left(\mathrm{mg} / \mathrm{cm}^{2}\right)\end{array}$ & $\begin{array}{c}\mathrm{W}_{\text {inh. }} \\
\left(\mathrm{mg} / \mathrm{cm}^{2}\right)\end{array}$ & $\theta$ & EI \% \\
\hline PEG & 303 & 14.00 & 11.73 & 0.162 & 16.214 \\
400 & 313 & 27.23 & 20.40 & 0.254 & 25.356 \\
& 323 & 55.33 & 30.73 & 0.445 & 44.460 \\
& 333 & 84.07 & 76.20 & 0.094 & 09.400 \\
\hline PEG 1500 & 303 & 14.00 & 07.47 & 0.466 & 46.642 \\
& 313 & 27.33 & 18.60 & 0.319 & 31.942 \\
& 323 & 55.33 & 39.70 & 0.282 & 28.248 \\
& 333 & 84.07 & 75.40 & 0.103 & 10.312 \\
\hline PEG 2000 & 303 & 14.00 & 04.87 & 0.652 & 65.214 \\
& 313 & 27.33 & 18.27 & 0.332 & 33.158 \\
& 323 & 55.33 & 34.47 & 0.377 & 37.701 \\
& 333 & 84.07 & 67.67 & 0.195 & 19.507 \\
\hline PEG 4000 & 303 & 14.00 & 08.13 & 0.419 & 71.427 \\
& 313 & 27.33 & 17.80 & 0.349 & 34.570 \\
& 323 & 55.33 & 28.53 & 0.484 & 48.436 \\
& 333 & 84.07 & 79.10 & 0.059 & 5.9117 \\
\hline
\end{tabular}


Table (2): The activation and adsorption thermodynamic parameters for the dissolution of aluminum in 1.0 $\mathrm{M}$ phosphoric acid in the absence and presence of $0.01 \mathrm{M}$ PEG inhibitors, from weight-loss measurements.

\begin{tabular}{|c|c|c|c|c|c|c|c|c|}
\hline \multirow[t]{2}{*}{ Add. } & \multirow{2}{*}{$\begin{array}{c}\mathrm{T} \\
(\mathrm{K})\end{array}$} & \multicolumn{4}{|c|}{ Activation parameters } & \multicolumn{3}{|c|}{ Adsorption parameters } \\
\hline & & $\begin{array}{c}\Delta \mathrm{E}_{\mathrm{a}} \\
\mathrm{kJ} / \mathrm{mole}\end{array}$ & $\begin{array}{c}\Delta \mathrm{G}_{\mathrm{a}} \\
\mathrm{kJ} / \mathrm{mole}\end{array}$ & $\begin{array}{c}\Delta \mathrm{H}_{\mathrm{a}} \\
\mathrm{kJ} / \mathrm{mole}\end{array}$ & $\begin{array}{c}\Delta \mathrm{S}_{\mathrm{a}} \\
\mathrm{kJ} / \text { mole. } \mathrm{K}\end{array}$ & $\begin{array}{c}\Delta \mathrm{G}_{\text {ads }} \\
\mathrm{kJ} / \mathrm{mole}\end{array}$ & $\begin{array}{c}\Delta \mathrm{H}_{\mathrm{ads}} \\
\mathrm{kJ} / \mathrm{mole}\end{array}$ & $\begin{array}{l}\mathrm{T} \Delta \mathrm{S}_{\mathrm{ads}} \\
\mathrm{kJ} / \mathrm{mol}\end{array}$ \\
\hline \multirow[t]{4}{*}{ Free } & 303 & 40.354 & 75.816 & 37.835 & -0.125 & & & \\
\hline & 313 & 40.354 & 77.738 & 37.752 & -0.127 & & & \\
\hline & 323 & 40.354 & 78.311 & 37.668 & -0.125 & & & \\
\hline & 333 & 40.354 & 78.463 & 37.585 & -0.122 & & & \\
\hline \multirow{4}{*}{$\begin{array}{r}\text { PEG } \\
400\end{array}$} & 303 & 40.940 & 76.415 & 38.420 & -0.125 & -22.563 & -31.232 & -8.667 \\
\hline & 313 & 40.940 & 77.077 & 38.337 & -0.123 & -24.772 & -33.727 & -8.954 \\
\hline & 323 & 40.940 & 79.258 & 38.254 & -0.126 & -27.866 & -37.107 & -9.240 \\
\hline & 333 & 40.940 & 79.832 & 38.171 & -0.125 & -23.058 & -32.585 & -9.526 \\
\hline \multirow{4}{*}{$\begin{array}{l}\text { PEG } \\
1500\end{array}$} & 303 & 60.289 & 76.963 & 57.770 & -0.063 & -107.048 & -114.303 & -7.254 \\
\hline & 313 & 60.289 & 77.346 & 57.687 & -0.062 & -108.963 & -116.457 & -7.493 \\
\hline & 323 & 60.286 & 78.058 & 57.604 & -0.063 & -111.972 & -119.705 & -7.733 \\
\hline & 333 & 60.289 & 78.799 & 57.520 & -0.063 & -112.030 & -120.003 & -7.972 \\
\hline \multirow{4}{*}{$\begin{array}{l}\text { PEG } \\
2000\end{array}$} & 303 & 61.729 & 77.485 & 59.209 & -0.060 & -102.978 & -110.024 & -7.046 \\
\hline & 313 & 61.729 & 77.646 & 59.126 & -0.059 & -102.915 & -110.194 & -7.279 \\
\hline & 323 & 61.729 & 78.367 & 59.043 & -0.059 & -106.738 & -114.250 & -7.511 \\
\hline & 333 & 61.729 & 79.224 & 58.960 & -0.063 & -107.509 & -115.253 & -7.744 \\
\hline \multirow{4}{*}{$\begin{array}{l}\text { PEG } \\
4000\end{array}$} & 303 & 64.083 & 76.883 & 61.564 & -0.050 & -71.931 & -83.728 & -8.667 \\
\hline & 313 & 64.083 & 77.603 & 61.481 & -0.051 & -73.526 & -82.481 & -8.953 \\
\hline & 323 & 64.083 & 79.082 & 61.397 & -0.054 & -77.386 & -86.626 & -9.239 \\
\hline & 333 & 64.083 & 77.978 & 61.314 & -0.050 & -72.292 & -81.818 & -9.525 \\
\hline
\end{tabular}


Table (3) Electrochemical parameters for aluminum in $1.0 \mathrm{M} \mathrm{H}_{3} \mathrm{PO}_{4}$ at different temperatures in presence of $0.01 \mathrm{M}$ of different PEG additives, from polarization measurements

\begin{tabular}{|c|c|c|c|c|c|c|}
\hline Inhibitor & $\mathrm{T}, \mathrm{K}$ & $\begin{array}{c}-E_{\text {corr }} \\
(\mathrm{mV})\end{array}$ & $\begin{array}{c}\mathrm{I}_{\text {corr }} \\
\left(\mathrm{mA} / \mathrm{Cm}^{2}\right)\end{array}$ & $\begin{array}{c}\mathrm{b}_{\mathrm{a}} \\
(\mathrm{mV} / \mathrm{dec})\end{array}$ & $\begin{array}{c}-b_{c} \\
(\mathrm{mV} / \mathrm{dec})\end{array}$ & EI.\% \\
\hline \multirow[t]{4}{*}{ Free } & 303 & 950 & 3.01 & 700.6 & 349.9 & \\
\hline & 313 & 970 & 3.4 & 1830.9 & 345.4 & \\
\hline & 323 & 985 & 3.98 & 1795.0 & 335.8 & \\
\hline & 333 & 1000 & 4.17 & 1358.0 & 306.7 & \\
\hline \multirow[t]{4}{*}{ PEG 400} & 303 & 890 & 1.99 & 1573.3 & 296.5 & 33.9 \\
\hline & 313 & 885 & 1.86 & 542.6 & 322.2 & 45.3 \\
\hline & 323 & 870 & 1.55 & 434.5 & 269.7 & 61.1 \\
\hline & 333 & 790 & 0.79 & 368.5 & 253.1 & 81.1 \\
\hline \multirow[t]{4}{*}{ PEG 1500} & 303 & 740 & 0.89 & 739.8 & 374.4 & 70.4 \\
\hline & 313 & 850 & 1.20 & 208.1 & 261.6 & 64.7 \\
\hline & 323 & 840 & 1.55 & 320.5 & 130.0 & 59.8 \\
\hline & 333 & 870 & 1.78 & 244.3 & 228.1 & 57.3 \\
\hline \multirow[t]{4}{*}{ PEG 2000} & 303 & 915 & 0.39 & 338.7 & 208.4 & 87.0 \\
\hline & 313 & 965 & 1.09 & 574.2 & 174.7 & 68.0 \\
\hline & 323 & 930 & 1.55 & 224.1 & 195.1 & 61.1 \\
\hline & 333 & 940 & 2.39 & 500.9 & 161.3 & 42.7 \\
\hline \multirow[t]{4}{*}{ PEG 4000} & 303 & 785 & 0.25 & 142.2 & 160.7 & 91.7 \\
\hline & 313 & 830 & 0.35 & 128.3 & 135.5 & 89.7 \\
\hline & 323 & 880 & 1.41 & 277.1 & 178.4 & 64.6 \\
\hline & 333 & 855 & 1.55 & 427.4 & 277.1 & 62.8 \\
\hline
\end{tabular}

Table (4): The activation and adsorption thermodynamic parameters, calculated from polarization measurements.

\begin{tabular}{|c|c|c|c|c|c|c|c|c|}
\hline \multirow[t]{2}{*}{ Add. } & \multirow{2}{*}{$\begin{array}{l}\mathrm{T} \\
(\mathrm{K})\end{array}$} & \multicolumn{4}{|c|}{ Activation parameters } & \multicolumn{3}{|c|}{ Adsorption parameters } \\
\hline & & $\begin{array}{c}\Delta \mathrm{E}_{\mathrm{a}} \\
\mathrm{kJ} / \mathrm{mol}\end{array}$ & $\begin{array}{c}\Delta \mathrm{G}_{\mathrm{a}} \\
\mathrm{kJ} / \mathrm{mol}\end{array}$ & $\begin{array}{c}\Delta \mathrm{H}_{\mathrm{a}} \\
\mathrm{kJ} / \mathrm{mol}\end{array}$ & $\begin{array}{c}\Delta \mathrm{S}_{\mathrm{a}} \\
\mathrm{kJ} / \mathrm{mol} . \mathrm{K}\end{array}$ & $\begin{array}{c}\Delta \mathrm{G}_{\mathrm{ads}} \\
\mathrm{kJ} / \mathrm{mol}\end{array}$ & $\begin{array}{c}\Delta \mathrm{H}_{\mathrm{ads}} \\
\mathrm{kJ} / \mathrm{mol}\end{array}$ & $\begin{array}{l}\mathrm{T} \Delta \mathrm{S}_{\text {ads }} \\
\mathrm{kJ} / \mathrm{mol}\end{array}$ \\
\hline \multirow{4}{*}{$\begin{array}{l}\text { PEG } \\
400\end{array}$} & 303 & 17.380 & 83.602 & 14.861 & 0.0068 & "57.958 & "58.115 & 0.1566 \\
\hline & 313 & 17.867 & 86.358 & 15.265 & 0.0078 & 58.624 & 58.785 & 0.1618 \\
\hline & 323 & 17.340 & 88.104 & 14.655 & 0.0056 & 58.781 & 58.948 & 0.1669 \\
\hline & 333 & 19.263 & 92.303 & 16.495 & 0.0109 & 57.820 & 57.992 & 0.1721 \\
\hline \multirow{4}{*}{$\begin{array}{l}\text { PEG } \\
1500\end{array}$} & 303 & 51.734 & 85.797 & 49.215 & 0.1201 & -16.048 & -16060.318 & -11.6030 \\
\hline & 313 & 49.209 & 84.475 & 46.607 & 0.1079 & -15.900 & -15912.276 & -11.9860 \\
\hline & 323 & 50.294 & 86.771 & 47.609 & 0.1076 & -15.847 & -15860.016 & -12.3689 \\
\hline & 333 & 51.444 & 89.134 & 48.675 & 0.1076 & -16.052 & -16065.612 & -12.7591 \\
\hline \multirow{4}{*}{$\begin{array}{l}\text { PEG } \\
2000\end{array}$} & 303 & 24.888 & 82.790 & 22.369 & 0.0315 & -57.467 & -57461.800 & 5.8015 \\
\hline & 313 & 25.462 & 85.359 & 22.860 & 0.0320 & -56.378 & -56372.413 & 5.9930 \\
\hline & 323 & 24.622 & 86.517 & 21.936 & 0.0282 & -57.367 & -57361.638 & 6.1844 \\
\hline & 333 & 25.121 & 89.017 & 22.352 & 0.0285 & -57.079 & -57072.877 & 6.3759 \\
\hline \multirow{4}{*}{$\begin{array}{l}\text { EG } \\
4000\end{array}$} & 303 & 11.655 & 81.937 & 9.136 & -0.0120 & -59.194 & -59211.639 & -16.8244 \\
\hline & 313 & 11.604 & 84.291 & 9.002 & -0.0121 & -60.529 & -60546.511 & -17.3797 \\
\hline & 323 & 11.486 & 86.580 & 8.801 & -0.0124 & -58.265 & -58283.409 & -17.9349 \\
\hline & 333 & 11.685 & 89.187 & 8.916 & -0.0117 & -59.853 & -59872.245 & -18.49026 \\
\hline
\end{tabular}




\section{Figures}

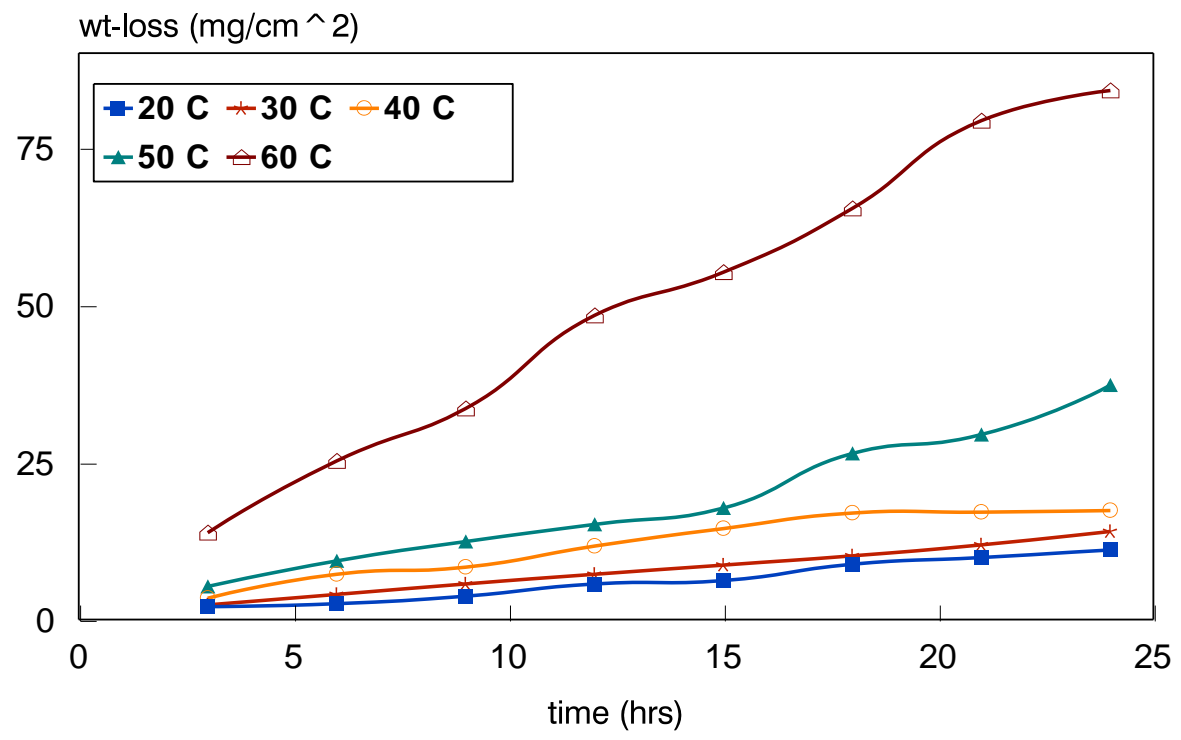

Fig. 1: The effect of time on the dissolution of aluminum in $\mathrm{O.1}_{6} \mathrm{M} \mathrm{H}_{3} \mathrm{PO}_{4}$ at different temperatures.
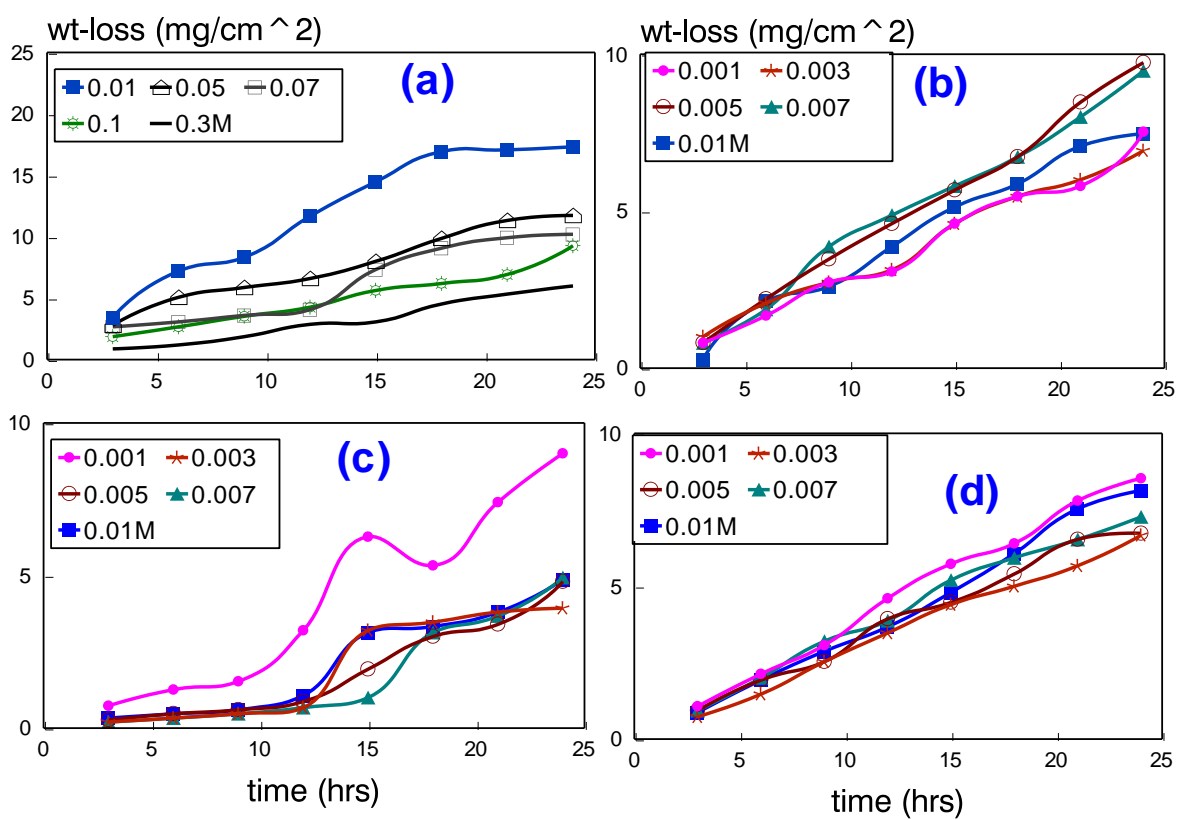

Fig. 2: The effect of concentrations of PEG additives $(a=400, b=1500, c=2000$, and $d$ $=4000$ ) on the corrosion of aluminum in $0.1 \mathrm{M} \mathrm{H}_{3} \mathrm{PO}_{4}$ at $30{ }^{\circ} \mathrm{C}$. 

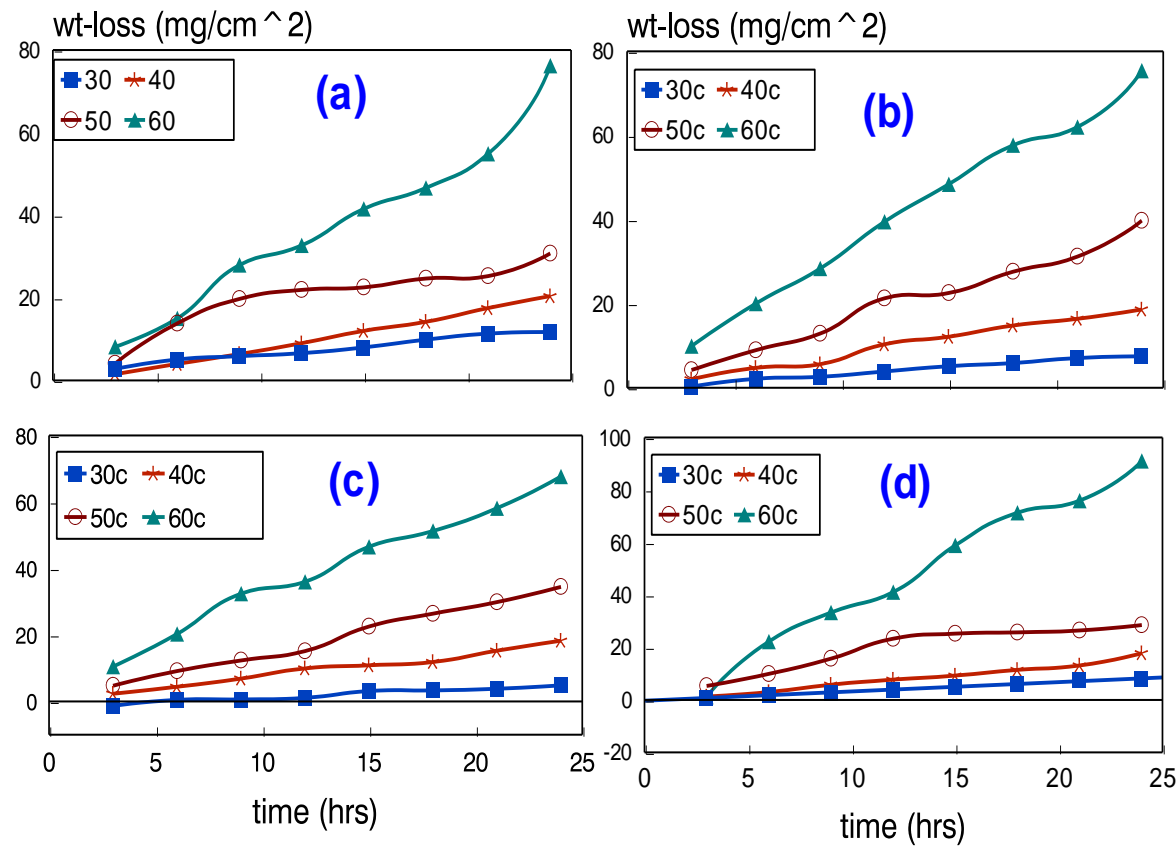

Fig. 3: The effect of temperatures on the dissolution of aluminum in $1.0 \mathrm{M} \mathrm{H}_{3} \mathrm{PO}_{4}$ in presence of $0.01 \mathrm{M}$ PEG additives $(a=400, b=1500, c=2000$, and $d=4000)$

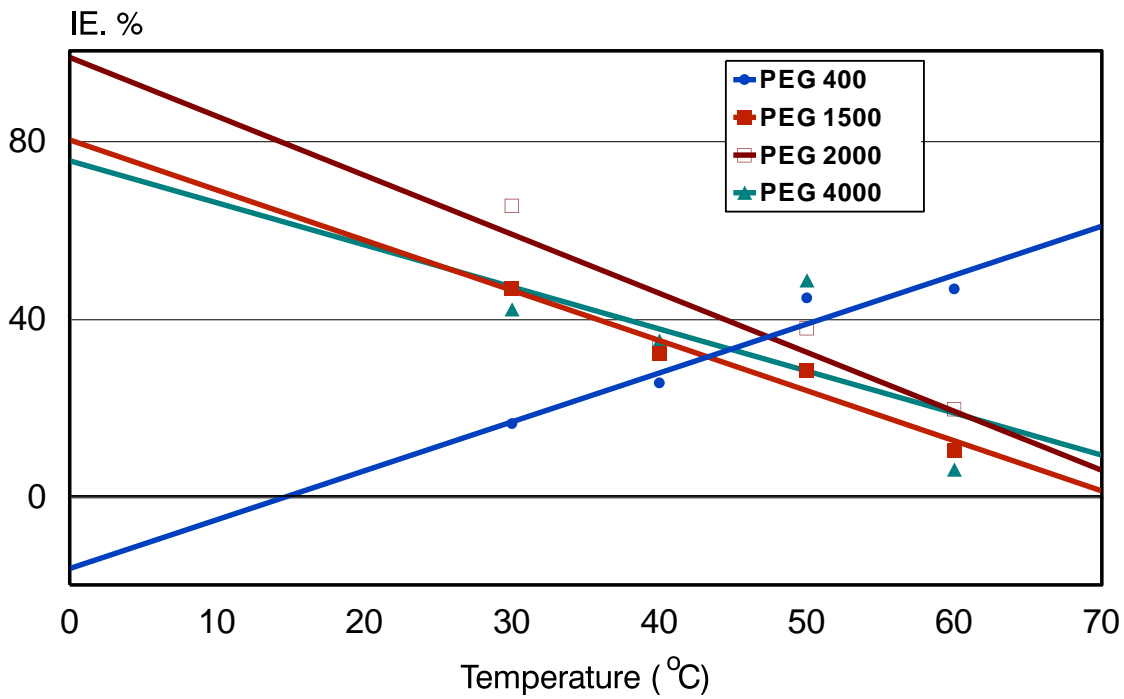

Fig. 4: The effect of temperatures on the inhibition efficiency of PEG additives. 

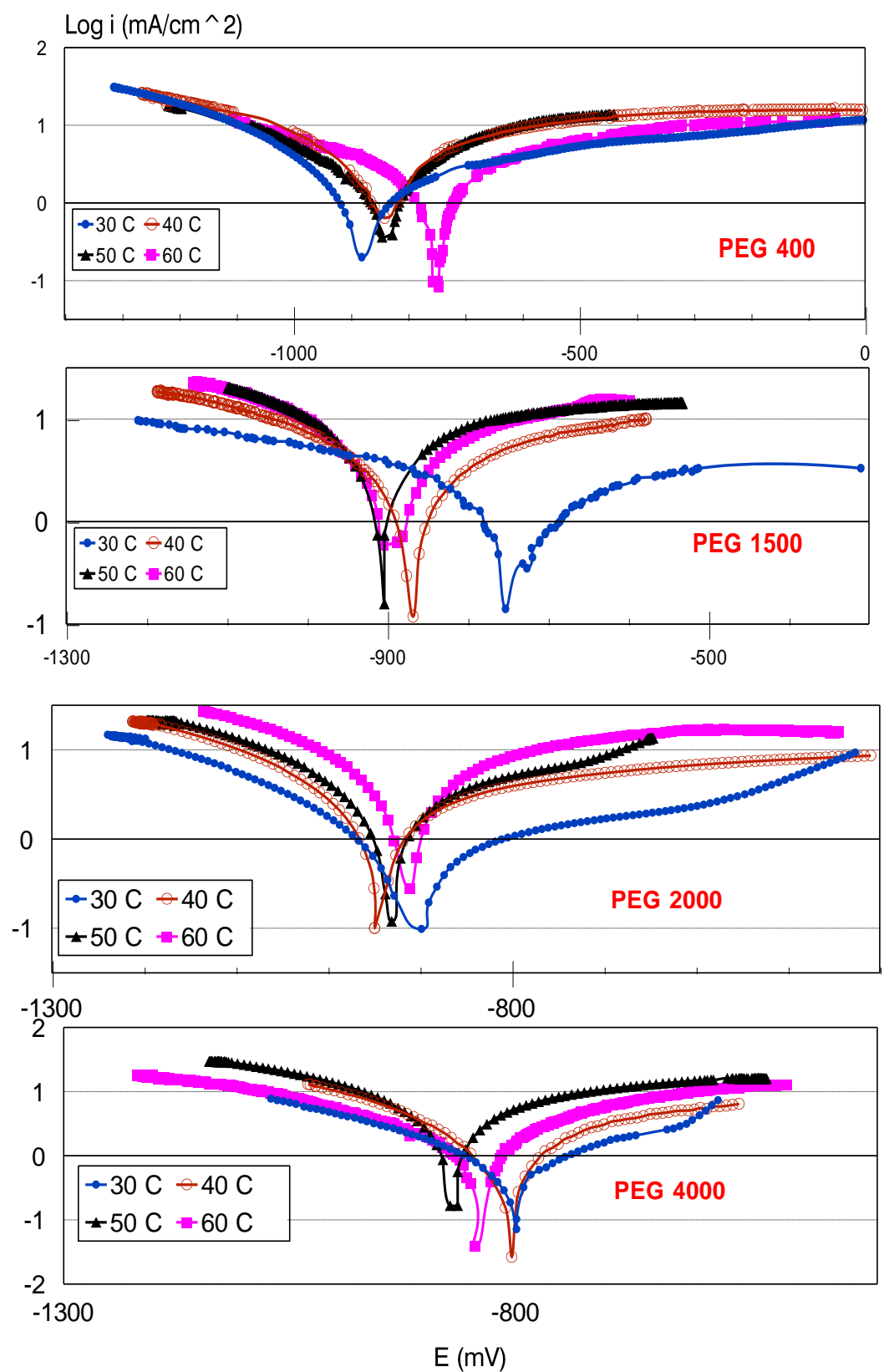

Fig. 5: Polarization curves measured for $\mathrm{Al}$ in $1.0 \mathrm{M} \mathrm{H}_{3} \mathrm{PO}_{4}$ in presence of PEG additives at different temperatures. 


\section{References:}

1. I. L. ROSENFELD, Corrosion Inhibitors, Mac. Graw. Hill, New York ,p.182 (1981).

2. Y. A. EL-AWADY AND A. I. AHMED. J. Ind. Chem. 24A, p. 601 (1985).

3. G. K. GOMMA AND M. H. WAHDAN. J. Mater. Chem. Phys. 39, p. 209 (1995).

4. C. M. BRETT, Corros. Sci. 33 p.203 (1992).

5. T. R. BECK, Electrochim. Acta 33 p. 1321 (1988).

6. M. ABDALLAH. J, Corros. Sci., 46, p1981- 1996 (2004).

7. H. ASHASSI-SORKHABI, B. SHAM, B. ALIGHOLIPOUR, D. SEIFZADEH. J. Applied Surface Science, 252, p4039- 4047 (2006).

8. S. L. Granese, Corrosion 44, p 322 (1988).

9. M. BOUKLAH, N. BENCHAT, B. HAMMOUTI, A. AOUNITI AND S. KERTIT. J. Materials Letters, 60, p1901-1905 (2006).

10. J.D. TALATI, M.N. DESAI AND A.M. TRIVEDI, Werkstoffe und Korros. (Mannheim), 10, 20 (1959).

11. J. D. TALATI AND R.M. MODI. Br. Corros. J, 10, 103 (1975).

12. F.A.CHAMPION, Corrosion Testing Procedures, London, 191 (1975).

13. YONSOK S. RANDY S. AND HYUK. Y. Polymer Engineering and Science. 38 (5). P 741-748 (1988).

14. A. AKSUT AND S, BILGIC, Corros. Sci. , 33, p379 (1992).

15. E. E. FOAD, EL-SHERBINI, S. M. ABD EL-WAHAB AND M. A. DEYAB, J. Mater. Chem. Phys. 89, p183 (2005).

16. I.Z.SELIM, J. Mater, Sci.Technol.,14, p313(1998).

17. G.M.PANCHENKOV and LEBEDEV, Chemical Kinetics and Catalysis, Mir Publishers, 147 (1976).

18. G.M.DOCRES, R.A.SUTULA, and B.F.LARRICKK, J.Electrochem. Soc., 130, p981 (1983).

19. N. M. GUAN, L. XUEMING and L. FEI. Mater. Chem. Phys. 86, p 59 (2004).

20. E. GELER and D. S. AZAMBUJA, Corr. Sci. 42, p631 (2000).

21. A. YURT, A. BALABAN, S.U. KANDEMIR, G. BEREKET AND B. ERK, Mater. Chem. Phys. 85, p420 (2004). 